\title{
ESTIMASI STATE OF CHARGE BATERAI LITHIUM POLYMER MENGGUNAKAN BACK PROPAGATION NEURAL NETWORK
}

\author{
${ }^{1}$ Mohammad Imron Dwi Prasetyo, ${ }^{2}$ Hasnira, ${ }^{3}$ Novie Ayub Windarko, dan ${ }^{4}$ Anang Tjahjono \\ ${ }^{134}$ Politeknik Elektronika Negeri Surabaya \\ Kampus PENS Jl. Raya ITS Sukolilo, Surabaya, 60111 \\ ${ }^{2}$ Politeknik Negeri Batam \\ Batam Centre, Jl. Ahmad Yani, Batam, 29461 \\ e-mail : ${ }^{1}$ imronz65@gmail.com, ${ }^{2}$ rhara@ @ polibatam.ac.id, ${ }^{3}$ ayub@pens.ac.id, ${ }^{4}$ anang.tj@ pens.ac.id
}

\begin{abstract}
Abstrak
Baterai merupakan salah satu komponen yang penting dalam konteks implementasi renewable energy. Jenis Baterai yang memiliki kepadatan dalam penyimpanan energy adalah lithium polymer. Parameter dalam baterai yang harus diperhatikan adalah estimasi State Of Charge (SOC). Pada umumnya estimasi SOC baterai menggunakan metode coloumb counting karena tingkat kesulitanya rendah. Namun terdapat kelemahan dari sisi ketergantungan terhadap utilitas sensor arus yang digunakan sebagai akumulasi dari integral arus yang masuk maupun arus yang keluar terhadap waktu. Dalam penelitian ini menyajikan Back Propagation Neural Network (BPNN) sebagai algoritma untuk estimasi SOC berdasarkan kurva karakteristik OCV - SOC. Kurva karakteristik OCV - SOC baterai didapatkan dari pengujian pulsa baterai. Tegangan, arus, dan waktu discharging baterai digunakan sebagai input layer BPNN pertama untuk estimasi Open Circuit Voltage (OCV). OCV akan dilearning sebagai input layer BPNN kedua untuk estimasi SOC baterai. Hasil dari simulasi estimasi SOC didapatkan galat rata-rata sebesar $0.479 \%$ terhadap SOC riil berdasarkan kurva karakteristik OCV - SOC.
\end{abstract}

Kata kunci: Back Propagation Neural Network (BPNN), State Of Charge (SOC), Open Circuit Voltage (OCV)

\begin{abstract}
The battery is an important component in the context of implementing renewable energy. The type of battery that has a density in energy storage is lithium polymer. The parameter in the battery that must be considered is the State of Charge (SOC) estimation. In general, the SOC battery estimation uses the coloumb counting method because the difficulty level is low. However, there are weaknesses in the dependence on the utility of the current sensor which is used as an accumulation of the integral of the incoming and outgoing currents over time. In this study presents Back Propagation Neural Network (BPNN) as an algorithm for estimating SOC based on OCV-SOC characteristic curves. The OCV-SOC characteristic curve of the battery is obtained from the battery pulse test. Battery voltage, current and discharging time are used as the first BPNN input layer for the estimation of Open Circuit Voltage (OCV). OCV will be learned as the second BPNN input layer for estimating battery SOC. The results of SOC estimation simulations obtained an average error of $0.479 \%$ against the real SOC based on the characteristic curve of OCV - SOC.
\end{abstract}

Keywords: Back Propagation Neural Network (BPNN), State Of Charge (SOC), Open Circuit Voltage (OCV) 


\section{Introduction}

Permasalahan energi bersih dan ramah lingkungan menjadi diskursus pembahasan di berbagai negara dewasa ini seiring dengan isu pemanasan global. Hal ini memicu untuk mencari berbagai alternatif dalam rangka membangun sumber energi baru terbarukan. Tak terkecuali di Indonesia yang telah menargetkan energi baru terbarukan sampai dengan tahun 2025 mencapai $17 \%$ dari konsumsi energi nasional [1]. Salah satu komponen prioritas energi baru terbarukan adalah baterai yang mampu menyimpan energi listrik dalam kapasitas waktu yang relatif lama.

Baterai sangat diperlukan dan memiliki urgensi tinggi karena berbagai jenis energi baru terbarukan seperti energi surya, angin, maupun air tidak dapat digunakan secara langsung bila energi yang dihasilkan kurang optimal. Oleh karena itu baterai yang digunakan untuk media penyimpanan energi listrik adalah jenis baterai skunder. Jenis baterai ini dapat dilakukan pengisian kembali muatan energi listrik (rechargeable). Selain itu baterai juga harus berjenis deep cycle battery, yaitu baterai yang dapat dikosongkan dengan prosentase yang cukup besar dari kapasitas maksimumnya [2].

Baterai Lithium merupakan salah satu tipe baterai yang sering digunakan dalam media penyimpanan energi listrik. Tipe baterai ini memiliki kemampuan penyimpanan dengan kepadatan energi yang tinggi, tegangan potensial open circuit tinggi, pengisian energi cepat, self discharge rendah, dan ramah lingkungan [3]. Salah satu contoh dari baterai tipe lithium adalah lithium polymer. Jika dibandingkan dengan baterai lithium jenis LiFePO4, lithium polymer lebih efektif secara performansi constant current discharge, power density maupun energi [4]. Pada baterai ini juga dapat digunakan fitur Battery Management System (BMS) sebagai pengatur charging dan discharging.

BMS merupakan sistem yang berfungsi untuk mengatur baterai dalam hal memantau, melakukan estimasi parameter, melindungi, memonitoring dan menyeimbangkan sel baterai. Informasi parameter pada BMS sangat penting untuk menentukan usia baterai [5]. Selain itu, informasi yang digunakan untuk menghindari overcharge dan overdischarge yang dapat menyebabkan kerusakan internal baterai secara permanen [5]. Salah satu fitur dalam BMS adalah menjaga SOC pada baterai. SOC dapat didefiniskan sebagai perbandingan antara kapasitas baterai yang tersisa terhadap kapasitas nominal baterai [6]. Pengukuran SOC tidak dapat dilakukan secara langsung. Dalam mendapatkan nilai SOC, banyak penelitian melakukan estimasi dengan menggunakan beberapa metode.

Metode yang umum dan mudah diimplementasikan adalah coulomb counting. Metode ini menggunakan informasi arus ketika proses charge dan discharge baterai, kemudian estimasi muatan coulomb melalui integral arus [7]. Akan tetapi metode ini memungkinkan adanya akumulasi galat hasil estimasi SOC karena diakibatkan ketergantungan hasil pembacaan sensor arus. Begitu juga dengan metode Open Voltage Circuit (OCV). Metode ini hanya dapat digunakan setelah baterai tidak terhubung dengan suplay maupun beban [8]. Sedangkan proses charging maupun discharging sebuah baterai berjalan secara kontinyu.

Disisi lain metode Machine Learning seperti Neural Network dapat memodelkan hubungan nonlinier antara input dan output berdasarkan data training, sehingga mampu melakukan estimasi yang akurat [9]. Salah satu algoritma dari Neural Network adalah BPNN (Back Propagation Neural Network). BPNN merupakan algoritma yang mampu digunakan untuk menyelesaikan permasalahan dalam sistem nonlinier [10].

Dalam penelitian ini membahas terkait dengan estimasi SOC baterai lithium polymer mengunakan metode BPNN (Back Propagation Neural Network) berdasarkan kurva karakteristik OCV-SOC. BPNN model dual neural digunakan untuk estimasi OCV baterai setelah dilakukan pengujian pulsa baterai, dan untuk estimasi SOC baterai. Arsitektur BPNN dibangun dengan menentukan jumlah hidden neuron berdasarkan pada persamaan matematik. Algoritma yang digunakan adalah Levenberg-Marquadt dan momentum yang bertujuan untuk mempercepat iterasi serta meminimalisir nilai MSE. Parameter MSE merupakan salah satu parameter untuk menentukan tingkat akurasi estimasi OCV dan SOC. Penerapan metode BPNN dimaksudkan agar arsitektur BPNN memiliki karakter yang tangguh (robust) sehingga akurasi SOC baterai Lithium Polymer hasil estimasi menjadi tinggi.

\section{Studi Pustaka}

\section{A. Pemodelan Baterai}

Baterai merupakan komponen elektrik yang dapat merubah energi kimia menjadi energi listrik. Setiap sel 


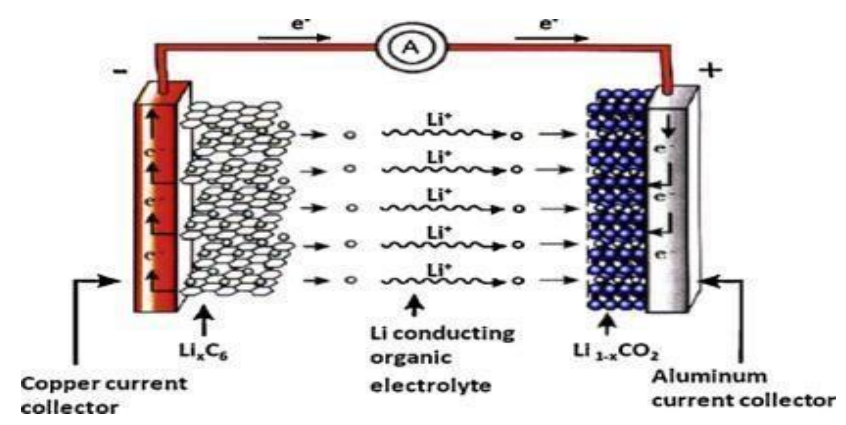

Gambar 1. Skema Elektron Baterai [11]

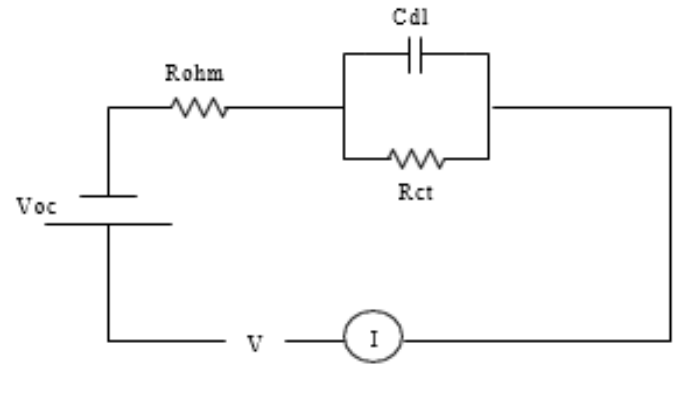

Gambar 2. Model Rangkaian Ekuivalen Thevenin Baterai [7] baterai memiliki katoda, anoda dan elektrolit yang berfungsi sebagai penghantar. Katoda sebagai kutub positif yang memiliki energi potensial lebih tinggi dibandingkan anoda. Kutub negatif atau anoda merupakan sumber elektron yang ketika dihubungkan dengan rangkaian eksternal mengalir dan memberikan energi listrik.

Gambar 1 menunjukkan skema baterai ion Lithium, dimana elektron mengalir dari anoda ke katoda. Prinsip kerja dari baterai adalah ketika baterai dihubungkan dengan rangkaian eksternal, elektrolit dapat berpindah sebagai ion dan terjadi reaksi kimia antara katoda dan anoda. Perpindahan ion tersebut mengalirkan arus listrik keluar pada baterai.

Model baterai berdasarkan rangkaian ekuivalen menggunakan komponen elektrik seperti resistor dan kapasitor untuk memodelkan charge dan discharge pada baterai ion Lithium [12]. Model rangkaian ekuivalen meliputi model Thevenin, model linier elektrikal, dan model RC baterai [12]. Model rangkaian ekuivalen Thevenin baterai ditunjukkan pada Gambar 2. Pemodelan baterai Thevenin dapat digunakan untuk melakukan prediksi OCV untuk menentukan SOC.

Berdasarkan pemodelan Thevenin baterai didapatkan persamaan matematik [7].

$V=V_{o c}+I R_{\Omega}+V_{d l}$

Untuk menentukan $\mathrm{V}_{\mathrm{dl}}$ dapat dihitung dengan persamaan 2 [7].

$\frac{d V_{d l}}{d t}+\frac{V_{d l}}{C_{d l} R_{c t}}=\frac{1}{C_{d l}}$

Dengan,

$V \quad=$ tegangan terminal baterai $(\mathrm{V})$.
$V_{o c}=$ tegangan open circuit baterai $(\mathrm{V})$.

$I \quad$ = arus baterai (Ampere).

$R_{\Omega}=$ resistansi $(\mathrm{Ohm})$.

$V_{d l}=$ tegangan di kapasitor $(\mathrm{V})$.

$C_{d l}=$ kapasitor baterai $(\mathrm{F})$.

$R_{c t}=$ resistor change transfer baterai (Ohm).

\section{B. State Of Charge (SOC)}

State of Charge (SOC) diartikan sebagai perbandingan sisa kapasitas pada baterai dari total kapasitas ketika baterai dilakukan charge penuh pada keadaan standar tertentu yang sama. SOC sering dinyatakan dalam persen, $100 \%$ berarti kapasitas penuh dan $0 \%$ berarti kapasitas kosong. Estimasi State of Charge (SOC) adalah bagian terpenting dalam persoalan di aplikasi baterai. Estimasi SOC yang tepat dapat menghindarkan dari gangguan sistem yang tidak dapat diperkirakan dan mencegah baterai dari overcharge dan overdischarge, yang dapat menyebabkan kerusakan permanen pada struktur internal baterai [13]. SOC dapat dituliskan secara matematik, yaitu [7];

$S O C=\left(\frac{Q_{\text {available }}}{Q_{\text {rated }}}\right) \times 100$

Dengan

$\mathrm{SOC}=$ state of charge baterai.

Qavailable = kapasitas tersedia baterai (Ah).

$\mathrm{Q}_{\text {rated }}=$ kapasitas nominal baterai (Ah).

Beberapa metode estimasi SOC baterai dapat diklasifikasikan menjadi empat kelompok [14], yaitu:

1. Pengukuran langsung (direct measurement) adalah metode yang digunakan terkait dengan fisik baterai, seperti tegangan dan impedansi. 
2. Estimasi metode book-keeping merupakan metode yang menggunakan arus discharge sebagai input dan intergral arus discharge untuk menghitung SOC.

3. Sistem adaptif merupakan sistem yang dirancang (self-designing) dan dapat langsung menyesuaikan (adjust) SOC untuk kondisi discharge yang berbeda.

4. Metode hibrid merupakan kombinasi beberapa metode yang memiliki kelebihan untuk estimasi SOC dan sesuai dengan kinerja yang optimal.

\section{Back Propagation Neural Network (BPNN)}

BPNN merupakan algoritma dari Artificial Neural Netwrok yang memiliki kemampuan adaptif untuk menyelesikan nonlinier problem dari sebuah sistem seperti estimasi SOC baterai [15].

Back Propagation Neural Network dapat dibangun untuk hubungan antara input dan output sehingga metode ini dapat digunakan untuk estimasi SOC baterai. BPNN termasuk sistem adaptif karena dapat merubah struktur untuk memecahkan masalah berdasarkan informasi eksternal maupun internal yang mengalir melalui network tersebut. Algoritma BPNN terdiri atas tiga fase, yaitu: fase maju, fase mundur dan fase modifikasi bobot untuk menurunkan galat yang terjadi [17].

Proses informasi pada BPNN terjadi pada neuron di input layer kemudian sinyal dikirimkan antar neuron-neuron melalui penghubung yang memiliki bobot (numerical weight) menuju output layer. Sinyal tersebut dapat bertambah atau berkurang jika dikalikan dengan nilai bobot (numerical weight) pada tiap penghubung antar neuron pada network. Berdasarkan Gambar 3 didapatkan persamaan (4) dan persamaan (5) [16].

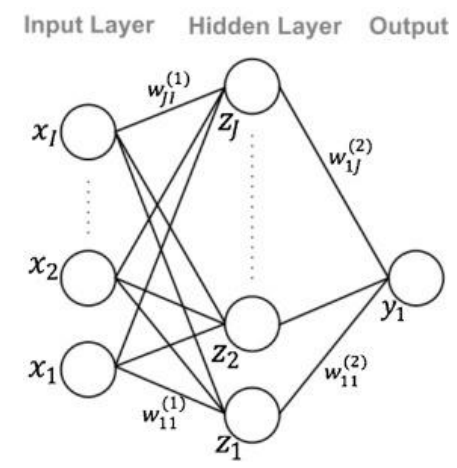

Gambar 3. Skematik Double Layer Neural Network

[16]

$$
z_{j}^{n}=\sum\left(w_{j i}^{(1)} x^{n-1} i+w_{j 0}^{(1)}\right)
$$

$a_{1}^{n}=\sum\left(w_{1 j}^{(2)} z^{n-1} i+w_{10}^{(2)}\right)$

$y_{j}^{n}=\sum\left(w_{j i}^{(1)} x^{n-1} i+w_{j 0}^{(1)}\right)$

Dimana,

$$
\begin{array}{ll}
x & =\text { input layer pertama } \\
Z & =\text { output layer pertama } \\
b & =\text { bias } \\
W & =\text { weight } \\
F(a) & =\text { fungsi aktivasi }
\end{array}
$$

Karakteristik dari BPNN, yaitu: arsitektur network, metode learning dan fungsi aktivasi [16]. BPNN dapat diimplementasikan untuk perkiraan fungsi atau analisis regresi, prediksi time series dan pemodelan. Selain itu, network ini dapat digunakan untuk pengambil keputusan pada pengurutan, pengolahan data, pengelompokkan kompresi serta program robot yang bergerak secara mandiri tanpa digerakan oleh manusia [17].

\section{Metode}

Penelitian ini bertujuan untuk estimasi SOC berdasarkan kurva karakteristik OCV-SOC pada baterai Lithium Polymer menggunakan dual neural BPNN. Kurva karakteristik OCV-SOC didapatkan dari hasil pengujian pulsa baterai Lithium Polymer baik saat kondisi charging maupun discharging. Kurva tersebut sebagai parameter target untuk estimasi OCV baterai menggunakan metode BPNN dengan data input tegangan charging atau discharging, arus charging atau discharging, dan waktu charging atau discharging. Hasil dari estimasi OCV digunakan sebagai input BPNN yang kedua untuk estimasi SOC baterai sebagai target berdasarkan kurva karakteristik OCV-SOC.

Adapun dasar pertimbangan BPNN sebagai metode berbasis kecerdasan buatan untuk estimasi SOC baterai yaitu dapat diimplementasikan secara sederhana dan kisaran galat yang dihasilkan berada pada batas toleransi. Selain itu, metode BPNN dapat diterapkan pada sistem yang tidak linier. Proses estimasi SOC berdasarkan kurva karakteristik ini secara lengkap tertera pada Gambar 4. 


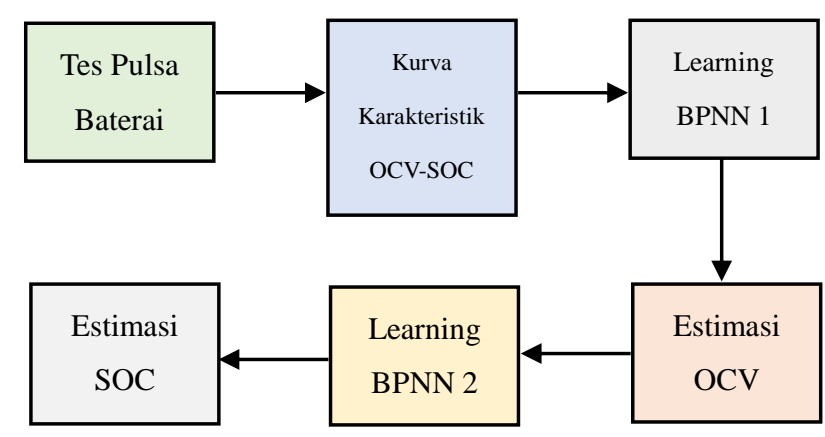

Gambar 4. Blok Diagram Sistem

\section{A. Tes Pulsa (Pulse Test) Baterai}

Pengujian pada tahap awal baterai yakni tes pulsa (pulse test) dengan tujuan untuk mendapatkan parameter OCV saat baterai kondisi open circuit.

Tes pulsa dilakukan pada baterai 1,3 Ah (spesifikasi pada Tabel 1) dengan kondisi charging baterai menggunakan GW Instek PSW-Series Programmable Switching DC Power Supply maupun discharging baterai sebesar 1,3 A atau 1C menggunakan DC Electronic Load Rigol DL3021 selama 4 menit. Kemudian baterai tidak dihubungkan dengan sumber tegangan listrik maupun dibebani (open circuit) selama 1 jam. Proses ini dilakukan berulang - ulang sebanyak 10 kali yang merepresentasikan SOC 0\% hingga $100 \%$ dengan step $10 \%$.

Baterai dikondisikan pada kondisi rest time (open circuit) selama 1 jam [8] dimaksudkan untuk mendapatkan nilai OCV yang diukur di terminal baterai. Waktu 1 jam dibutuhkan karena settling time yang dibutuhkan tegangan terminal baterai pada kondisi rest time tepat setelah charge ataupun discharge untuk mencapai keadaan tunak (steady state). Gambar 5 merupakan dokumentasi foto pengujian pulsa baterai, sedangkan Gambar 6 merupakan hasil pengujian pulsa baterai.

Tabel 1. Spesifikasi Baterai Lithium Polymer Turnigy

\begin{tabular}{lll}
\hline Parameter & & Spesifikasi \\
\hline Minimum Capacity & $:$ & 1300mAh \\
Configuration & $:$ & $3 \mathrm{~S} 1 \mathrm{P} / 11.1 \mathrm{v} / 3$ Cell \\
Constant Discharge & $:$ & $30 \mathrm{C}$ \\
Peak Discharge & $:$ & $40 \mathrm{C}$ \\
(10sec) & & \\
Pack Weight & $:$ & $107 \mathrm{~g}$ \\
Pack Size & $:$ & $78 \times 34 \times 23 \mathrm{~mm}$ \\
Charge Plug & $:$ & JST-XH \\
Discharge plug & $:$ & XT60 \\
\hline
\end{tabular}

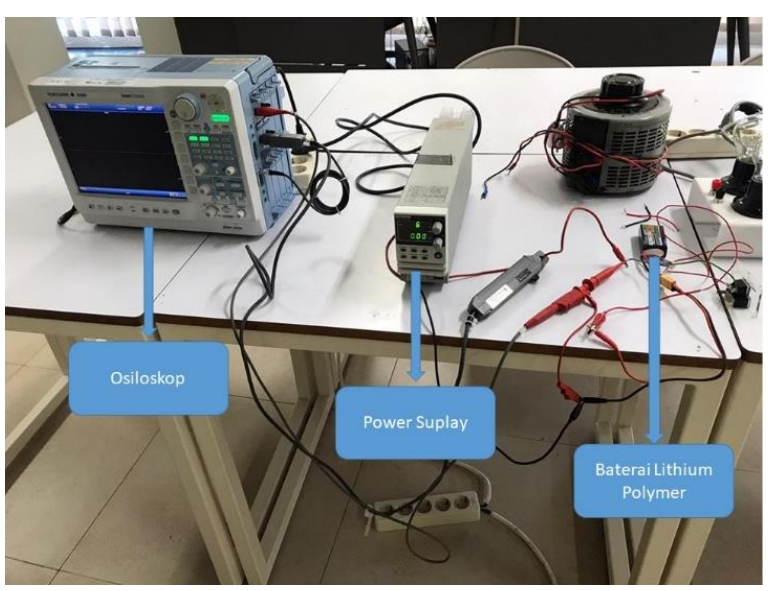

(a)

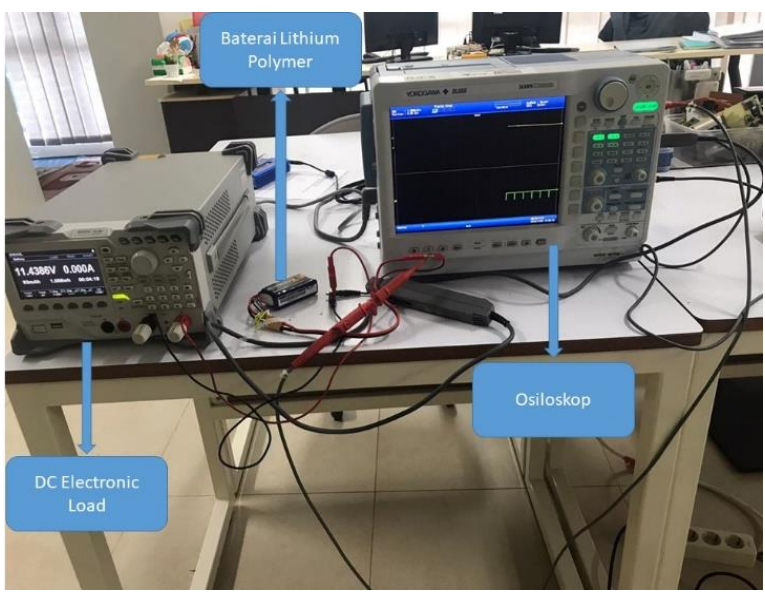

(b)

Gambar 5. Dokumentasi Foto Pengujian Tes Pulsa Baterai (a) Charging, (b) Discharging

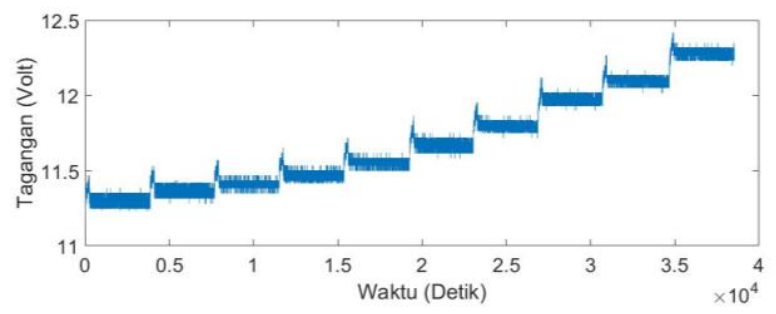

(a)

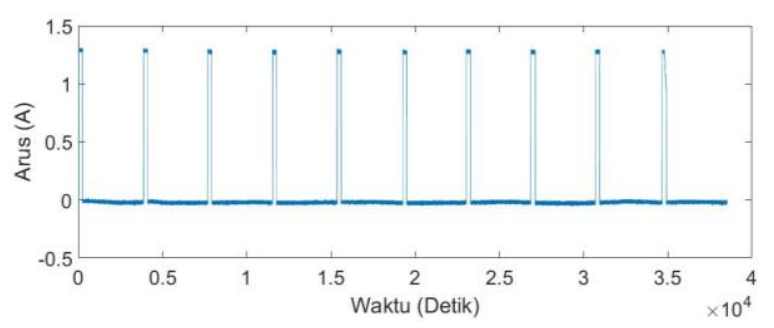

(b) 


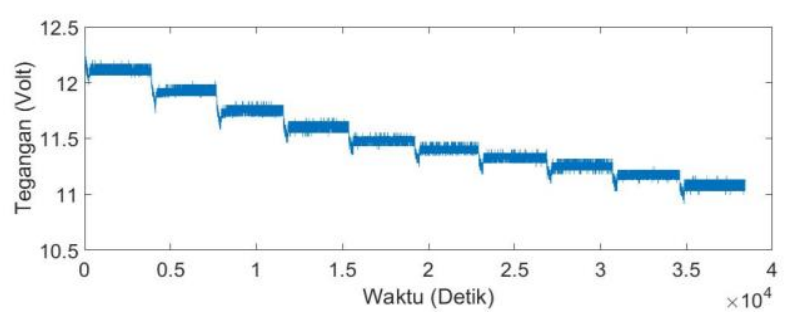

(c)

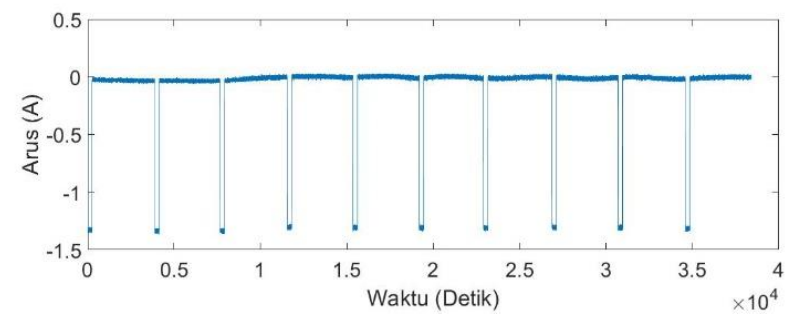

(d)

Gambar 6. Hasil Pengujian Pulsa Baterai (a) Sinyal

Tegangan Charging, (b) Sinyal Arus Charging, (c)

Sinyal Tegangan Discharging, (d) Sinyal Arus

\section{Discharging}

\section{B. Arsitektur Dual BPNN}

Arsitektur BPNN (Back Propagation Neural Network) terdiri input layer, hidden layer dan output layer. Setiap layer memiliki neuron yang dapat menghubungkan neuron satu ke neuron lainnya pada layer yang berbeda. Tahap ini bertujuan untuk menentukan jumlah hidden neuron pada arsitektur BPNN. Untuk menentukan jumlah hidden neuron menggunakan persamaan (6) [18] melalui eksperimen.

Pada Gambar 7 menunjukkan flowchart untuk menentukan jumlah hidden neuron. Langkah pertama adalah sinyal tegangan charging dan discharging, arus charging dan discharging, serta waktu charging dan discharging [V I t] dari pengujian pulsa baterai dinormalisasi kemudian dikomputasi pada BPNN untuk estimasi OCV. Proses komputasi menghasilkan sinyal output. Proses ini terdiri atas training data dan testing data pada network. Galat didapatkan ketika nilai target dan output berbeda. Proses iterasi di network berlangsung secara terus menerus hingga didapatkan nilai bobot (numerical weight) yang sesuai. MSE, waktu iterasi, jumlah iterasi, nilai galat dan nilai korelasi antara target dan output merupakan parameter hasil komputasi setelah proses training data. Training dalam penelitian ini menggunakan command 'nntool' pada Matlab, dengan fungsi aktivasi tansig dam metode learning Levenberg Marquardt Algorithm.

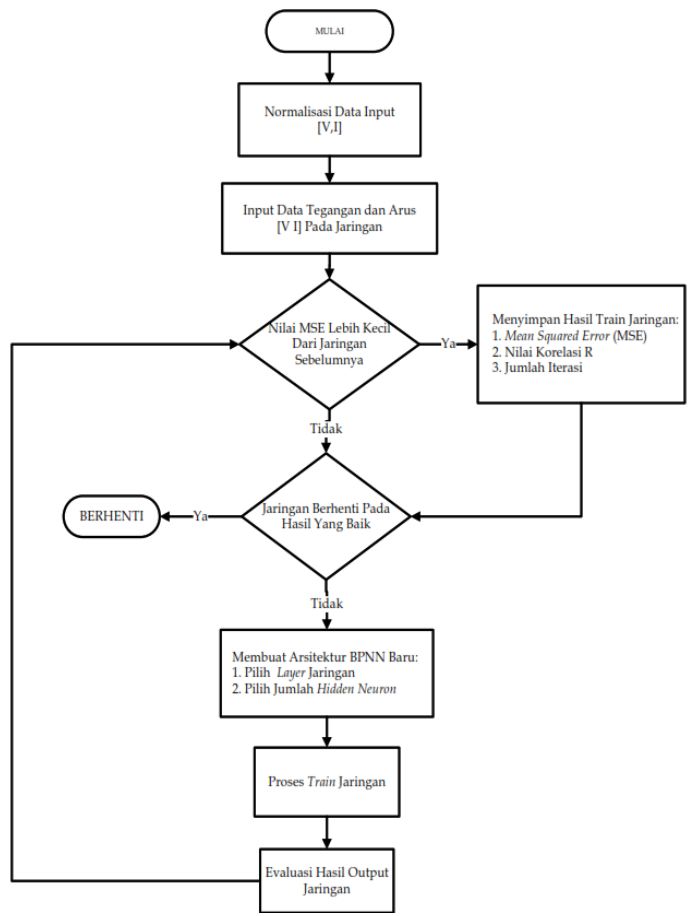

Gambar 7. Flowchart untuk Menentukan Arsitektur BPNN

Tabel 1. Jumlah Hidden Neuron dan Nilai Regresi pada BPNN untuk Estimasi OCV

\begin{tabular}{|l|l|l|l|}
\hline$\sigma$ & $\begin{array}{l}\text { Hidden } \\
\text { Neuron (hn) }\end{array}$ & Regresi & MSE \\
\hline 1 & 3 & 0.99728 & 0.0005692 \\
\hline 2 & 4 & 0.99844 & 0.0003270 \\
\hline 3 & 5 & 0.99945 & 0.0001192 \\
\hline 4 & 6 & 0.9998 & 0.0000417 \\
\hline 5 & 7 & 0.99872 & 0.0002627 \\
\hline 6 & 8 & 0.99998 & 0.0000037 \\
\hline 7 & 9 & 0.99999 & 0.0000012 \\
\hline 8 & 10 & 0.99999 & 0.0000011 \\
\hline 9 & 11 & 0.99999 & 0.0000016 \\
\hline 10 & 12 & 0.99999 & 0.0000030 \\
\hline
\end{tabular}

Pada penelitian ini, jumlah neuron pada input layer (in) adalah 3. Untuk jumlah neuron pada output layer (on) adalah 1. Untuk kisaran nilai $\sigma$ adalah antara 1 hingga 10.

$h n=\sqrt{i n+o n}+\sigma$

Pada Tabel 1 memuat hasil perhitungan jumlah hidden neuron, nilai regresi hasil training dan MSE pada arsitektur BPNN.

Berdasarkan Tabel 1, menunjukkan bahwa jumlah hidden neuron 10 memiliki nilai regression mendekati 
1 dan nilai MSE terendah. Pada Gambar 8 menampilkan arsitektur BPNN setelah dilakukan training untuk estimasi OCV dengan menggunakan jumlah hidden neuron 10 dan Gambar 9 merupakan hasil nilai regression setelah dilakukan training.

BPNN yang pertama setelah dilakukan training dengan menghasilkan estimasi OCV baterai, maka selanjutnya dengan langkah yang sama seperti pada flowchart pada Gambar 7, digunakan untuk menentukan arsitektur BPNN untuk estimasi SOC baterai.

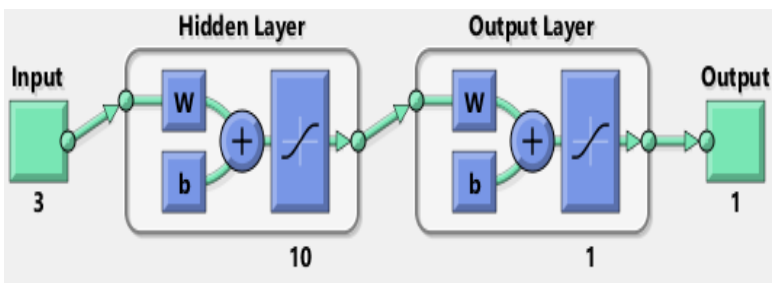

Gambar 8. Arsitektur BPNN untuk Estimasi OCV
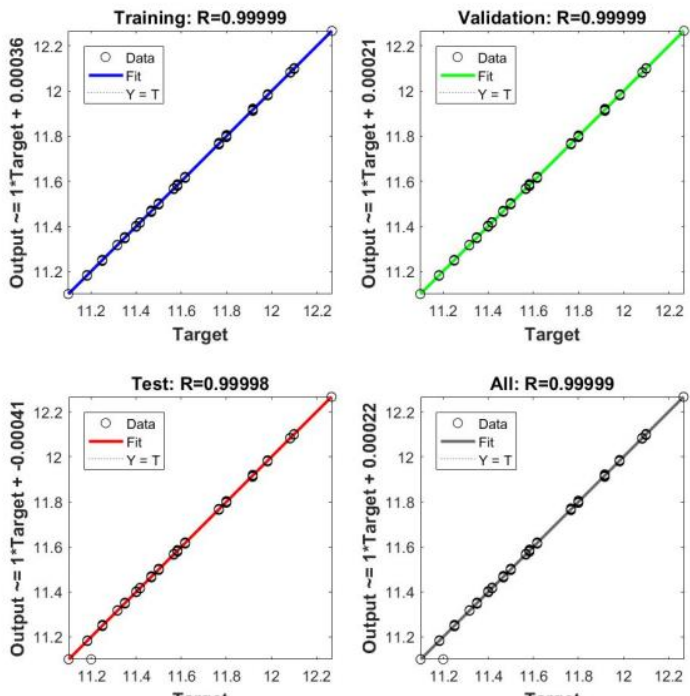

Gambar 9. Hasil Regression ANN Estimasi OCV

Arsitektur BPNN untuk estimasi SOC baterai menggunakan satu variabel input yakni OCV hasil estimasi BPNN yang pertama, dan sebagai target adalah SOC berdasarkan kurva karakteristik yang sudah didapatkan melalui tes pulsa baterai. Hidden neuron yang digunakan adalah 12, berdasarkan perhitungan pada Persamaan (6). Tabel 2 memuat hasil perhitungan jumlah hidden neuron beserta nilai regresi hasil training pada arsitektur BPNN untuk estimasi SOC baterai.

Dalam Tabel 2, menunjukkan bahwa jumlah hidden neuron 12 memiliki nilai regression mendekati 1 dan nilai MSE terendah. Pada Gambar 10 menampilkan arsitektur BPNN setelah dilakukan training untuk estimasi SOC dan Gambar 11 merupakan hasil nilai regression setelah dilakukan training.

Tabel 2. Jumlah Hidden Neuron dan Nilai Regresi pada BPNN untuk Estimasi SOC

\begin{tabular}{|l|l|l|r|}
\hline$\sigma$ & $\begin{array}{l}\text { Hidden } \\
\text { Neuron }(\mathrm{hn})\end{array}$ & Regresi & \multicolumn{1}{l|}{ MSE } \\
\hline 1 & 3 & 0.98681 & 22.0866 \\
\hline 2 & 4 & 0.9959 & 23.5714 \\
\hline 3 & 5 & 0 & 3322.6958 \\
\hline 4 & 6 & 0.99175 & 14.035 \\
\hline 5 & 7 & 0.99205 & 13.3829 \\
\hline 6 & 8 & 0.99348 & 11.0634 \\
\hline 7 & 9 & 0.99245 & 12.775 \\
\hline 8 & 10 & 0.85671 & 815.317 \\
\hline 9 & 11 & 0.9984 & 2.7092 \\
\hline 10 & 12 & 0.99846 & 2.5674 \\
\hline
\end{tabular}

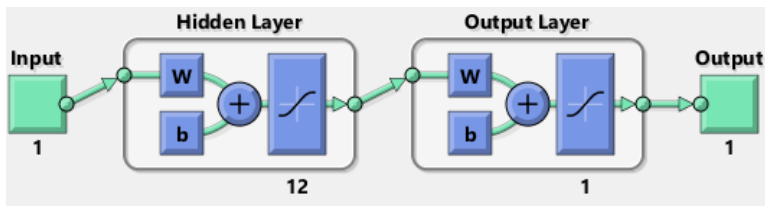

Gambar 10. Arsitektur BPNN untuk Estimasi SOC
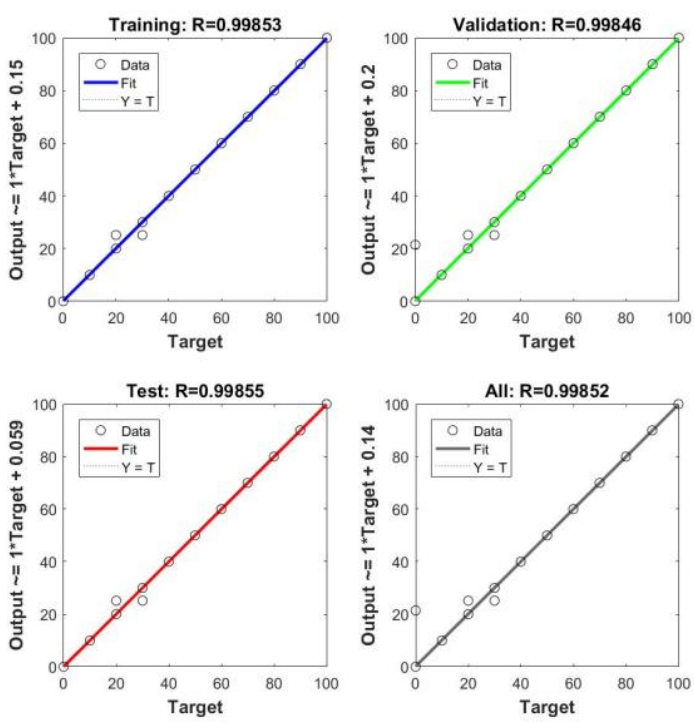

Gambar 11. Hasil Regression ANN Estimasi SOC

Secara keseluruhan arsitektur dual neural network tertera pada Gambar 12. Dual neural network ditujukan untuk estimasi OCV dengan input tegangan, arus, dan waktu charging maupun discharging baterai 
pada neural pertama, serta estimasi SOC baterai dengan input OCV hasil training neural pertama pada neural kedua. Semua training dalam mendapatkan nilai regression sebagaimana pada Tabel 1 dan Tabel 2 menggunakan command 'nntool' dalam Matlab.

\section{Hasil dan Pembahasana}

Dalam bab ini menjelaskan terkait dengan perbandingan estimasi SOC menggunakan BPNN berdasarkan kurva karakteristik OCV-SOC baterai dengan SOC riil baterai.

\section{A. Kurva Karakteristik OCV-SOC Baterai}

Pada penelitian ini menggunakan baterai lithium polymer $1300 \mathrm{mAh} 3$ cell dalam state charging $1 \mathrm{C}$ dan discharging $1 \mathrm{C}$. Pengujian pertama dilakukan dengan charging baterai ketika SOC $0 \%$ atau tegangan terminal 11.1 volt hingga tegangan charging mencapai 12.6 volt sebagai tegangan cut off baterai. Waktu yang dibutuhkan untuk charging baterai $1 \mathrm{C}$ mencapai SOC 100\% adalah 41 menit. Sedangkan waktu untuk discharging baterai $1 \mathrm{C}$ dari tegangan terminal 12.4 volt hingga mencapai tegangan discharge 11.0 volt sebagai tegangan cut off baterai lithium polymer adalah 43 menit. Dari kedua waktu di atas digunakan untuk lamanya charging maupun discharging baterai ketika test pulsa untuk mendapatkan kurva karakteristik OCV - SOC baterai setiap 10\% SOC. Gambar 13 merupakan hasil kurva karakteristik OCV - SOC baterai lithium polymer.

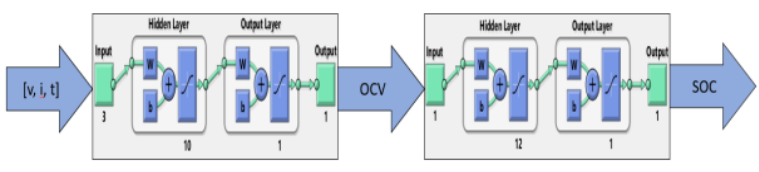

Gambar 12. Arsitektur Dual Nerual BPNN

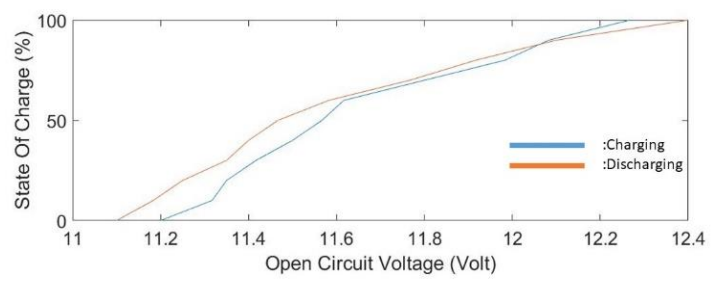

Gambar 13. Kurva Karakteristik OCV-SOC

\section{B. Estimasi SOC Baterai Menggunakan BPNN}

Dari kurva karakteristik OCV - SOC baterai lithium polymer, maka untuk estimasi SOC harus mendapatkan nilai estimasi OCV terlebih dahulu. Estimasi OCV dilakukan dengan menggunakan algoritma neural network. Input dari BPNN pertama yakni tegangan, arus, dan waktu charging maupun discharging. Input tersebut dilakukan training di matlab melalui command 'nntool' dengan 1 hidden layer dan 10 hidden neuron untuk men-generate BPNN di Simulink matlab sebagaimana Gambar 15.

Hasil generate BPNN pertama estimasi OCV baterai digunakan sebagai input pada BPNN kedua dengan target SOC. Nilai SOC estimasi dibandingkan dengan hasil SOC aktual berdasarkan kurva karakteristik OCV - SOC baterai. Gambar 14 merupakan hasil perbandingan estimasi SOC baterai dengan SOC aktual sesuai dengan pengukuran tes pulsa.

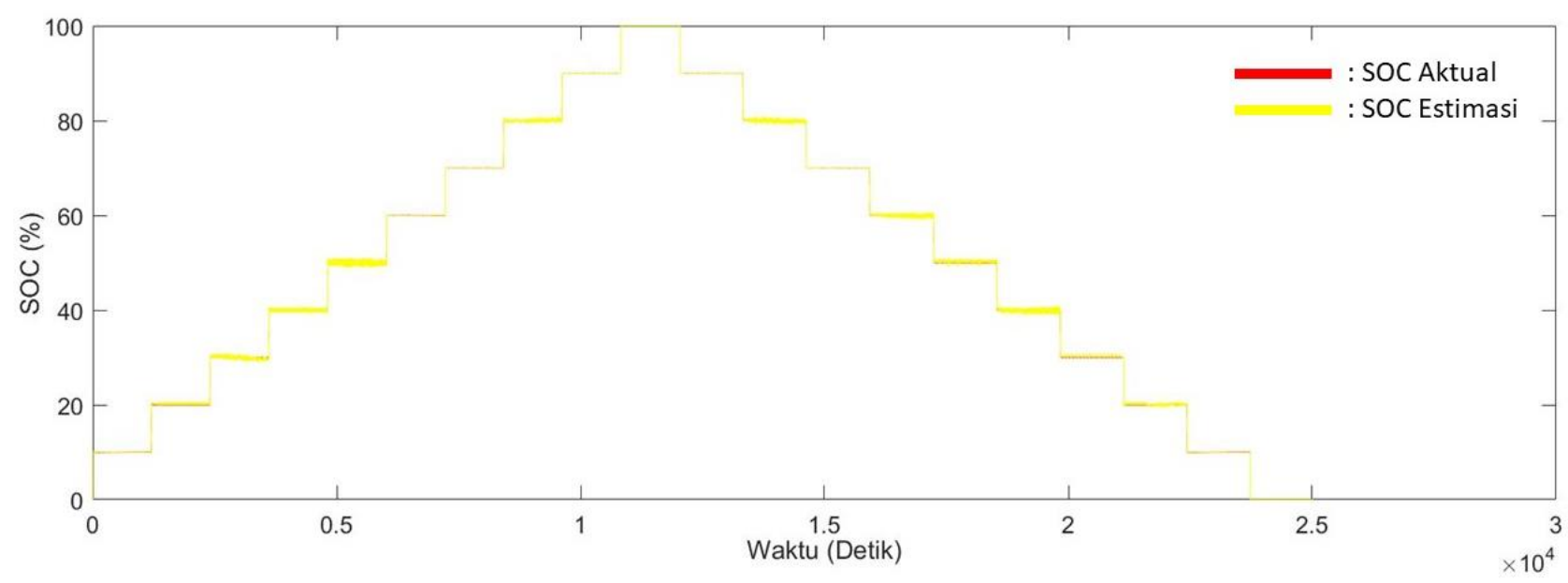

Gambar 14. Hasil Estimasi SOC Baterai Menggunakan BPNN 


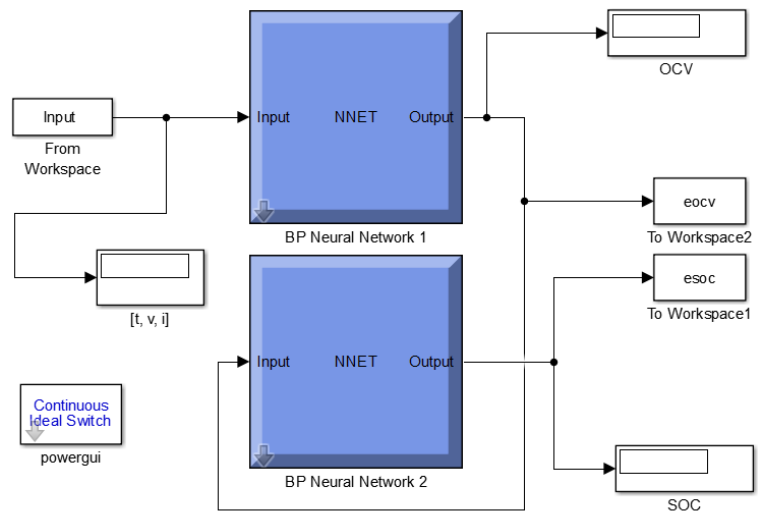

Gambar 15. Simulink Simulasi Estimasi SOC

Hasil dari estimasi SOC menggunakan metode BPNN, didapatkan bahwa galat maksimum yang terjadi sebesar $2.998 \%$, sedangkan galat rata-rata yakni $0.479 \%$. Galat didapatkan dengan membandingkan prosentase selisih antara SOC aktual dengan SOC estimasi.

Estimasi SOC menggunakan BPNN terbukti mampu menghasilkan galat yang sangat kecil. BPNN memiliki keunggulan dengan karakteristik yakni adabtable, artinya dapat menyesuaikan pola data yang acak dan variatif. Dalam konteks penelitian ini mampu mengenali perubahan pulsa baterai baik saat charging maupun discharging. Hal ini disebabkan karena bobot (numerical weight) yang dapat berubah sampai proses iterasi selesai. Jika dibandingkan dengan metode coulomb counting [19] dan combined coulomb counting and fuzzy logic method [20], BPNN juga mampu melakukan estimasi SOC baterai lebih presisi.

\section{Kesimpulan}

Dari hasil simulasi estimasi SOC berdasarkan kurva karakteristik OCV - SOC menunjukkan bahwa metode Back Propagation Neural Network (BPNN) sangat kompatibel digunakan dalam sistem yang nonlinier seperti pada estimasi SOC baterai. Terlihat dari galat rata-rata yang terjadi dalam estimasi SOC baterai lithium polymer ini mencapai $0.479 \%$.

\section{Ucapan Terima Kasih}

Ucapan terima kasih yang setinggi-tingginya kami haturkan kepada rekan-rekan Lab. Renewable Energy Politeknik Elektronika Negeri Surabaya (PENS) dan Lab. Robotik Universitas Airlangga yang telah memberikan kesempatan dalam melaksanakan penelitian ini.

\section{Daftar Pustaka}

A. H. Budiman, P. Teknologi, K. Dan, K. Energi, B. Pengkajian, and D. A. N. Penerapan, "Pengembangan Energy Storage," Kaji. Roadmap Pengemb. Energy Storage untuk Smart Grid Syst., p. 46, 2013.

G. J. May, A. Davidson, and B. Monahov, "Lead batteries for utility energy storage: A review," J. Energy Storage, vol. 15, pp. 145-157, 2018.

[3] L. Long, S. Wang, M. Xiao, and Y. Meng, "Polymer electrolytes for lithium polymer batteries," J. Mater. Chem. A, vol. 4, no. 26, pp. 10038-10039, 2016.

[4] C. Huai, P. Liu, and X. Jia, "Measurement and analysis for lithium battery of high-rate discharge performance," Procedia Eng., vol. 15, pp. 2619-2623, 2011.

[5] J. Kim, S. Lee, and B. H. Cho, "Complementary cooperation algorithm based on DEKF combined with pattern recognition for SOC/capacity estimation and SOH prediction," IEEE Trans. Power Electron., vol. 27, no. 1, pp. 436-451, 2012.

[6] J. Klee Barillas, J. Li, C. Günther, and M. A. Danzer, "A comparative study and validation of state estimation algorithms for Li-ion batteries in battery management systems," Appl. Energy, vol. 155, pp. 455-462, 2015.

[7] Y. Su, "Switching-based state-of-charge estimation of lithium-ion batteries Switching-Based State-of-Charge Estimation of Lithium-Ion Batteries,” 2011.

[8] L. W. Kang, X. Zhao, and J. Ma, "A new neural network model for the state-of-charge estimation in the battery degradation process," Appl. Energy, vol. 121, pp. 20-27, 2014.

[9] F. Yang, Y. Xing, D. Wang, and K. L. Tsui, “A comparative study of three model-based algorithms for estimating state-of-charge of lithium-ion batteries under a new combined dynamic loading profile," Appl. Energy, vol. 164, pp. 387-399, 2016. 
[10] S. Jeon, J. J. Yun, and S. Bae, "Comparative study on the battery state-of-charge estimation method," Indian J. Sci. Technol., vol. 8, no. 26, pp. 1-6, 2015.

[11] B. Scrosati and J. Garche, "Lithium batteries: Status, prospects and future," J. Power Sources, vol. 195, no. 9, pp. 2419-2430, 2010 .

[12] R. Ahmed, "Modeling and State of Charge Estimation of Electric Vehicle," Dr. Diss., 2014.

[13] J. Xie, J. Ma, and K. Bai, "Enhanced coulomb counting method for state-of-charge estimation of lithium-ion batteries based on peukert's law and coulombic efficiency," J. Power Electron., vol. 18, no. 3, pp. 910-922, 2018.

[14] W.-Y. Chang, "The State of Charge Estimating Methods for Battery: A Review," ISRN Appl. Math., vol. 2013, no. 1, pp. 1-7, 2013.

[15] C. Dong and G. Wang, "Estimation of power battery SOC based on improved BP neural network," 2014 IEEE Int. Conf. Mechatronics Autom. IEEE ICMA 2014, pp. 2022-2027, 2014.

[16] L. Xiao, X. Chen, and X. Zhang, “A joint optimization of momentum item and levenberg-marquardt algorithm to level Up the BPNN's generalization ability," Math. Probl. Eng., vol. 2014, no. November 2015, 2014.

[17] L. Fausett, "Fundamentals Of Neural Network Architectures, Algorithms, and Applications," Inc.,New Jersey, vol. 116, no. 0, pp. 1-476, 1994.

[18] S. Tong, J. H. Lacap, and J. W. Park, "Battery state of charge estimation using a load-classifying neural network," J. Energy Storage, vol. 7, pp. 236-243, 2016.

[19] L. H. Dong Guo, "A Novel Algorithm for SOC using Simple Iteration and Coulomb Counting Method," 2018 IEEE Student Conf. Electr. Mach. Syst., no. 1, pp. 1-4.

[20] D. Saji, P. S. Babu, and K. Ilango, "SoC Estimation of Lithium Ion Battery Using
Combined Coulomb Counting and Fuzzy Logic Method," 2019 4th IEEE Int. Conf. Recent Trends Electron. Information, Commun. Technol. RTEICT 2019 - Proc., pp. 948-952, 2019. 